\title{
SKILL DEVELOPIMENT PRACTICES IN INDIAN SME FOUNDRIES
}

KEY WORDS: Foundries, Skill Development, Small and Medium Enterprises, and VUCA World

\section{Shailaja Hiremath \\ Dr. P. M. Kulkarni*}

Assistant Professor, KLS Institute of Management Education and Research Hindwadi, Belagavi, Karnataka, India-590011.

Professor, Department of MBA, KLS Gogte Institute of Technology, Belagavi. *Corresponding Author

Small and Medium Enterprises (SMEs) play a very vital role in the development of Indian economy. The business scenario for SMEs has not been so easy looking at the competitiveness, concern for quality and cost in the global markets. Foundries in India are not an exception to manage their sustainability in the VUCA world. This is due to the changing technology and innovative business processes and models. Looking at the present condition, Skill Development has become a critical issue in Indian Small and Medium Enterprises, particularly the foundries falling in this category. This paper presents the study to find out the skill development practices in foundries in three geographical locations, which are very well known for as Foundry Clusters in India. The study has used survey method to collect the necessary information and suitable descriptive statistical analysis is carried out to achieve the research objective. The findings suggest that foundries are learning to cope with the skill development demands, but still there is a long way to go.

\section{INTRODUCTION}

The technological developments in the foundry industry has made the units to improve their casting processes and the way day to day operations to be managed [1]. The situation requires the skilled manpower to keep the activity going. The foundries have been the base industry for other manufacturing industry such as automotive, agriculture equipment, heavy engineering etc. Majority of the Indian casting unis falls in the category of MSMEs and sector is now the second largest producer of castings [2]. So, it is important to understand the need of the hour to modernize the SME foundries as well. Any change in the process or technology requires the organizations to train their employees to enhance their skill levels by reskilling and provide upskilling. To do so, management of the foundries need to have the philosophy to encourage skill development practices and ensure the suitable organizational culture that support such practices. This study was undertaken to find out the skill development practices as perceived by the employees working in foundries, operating in North Karnataka and South-West part of Maharashtra, as these regions are well known foundry clusters with a legacy of Grey Iron castings manufacturing.

\section{LITERATURE REVIEW}

Wong et al., (1997) [3] have observed in their research, that 'it is not very easy task to convince SMEs to invest in training as it is difficult to see the direct impact on profit of the unit'. There are fewer studies found in academic research about characteristics of HR activities, specially training activities in foundries in India. SMEs have their own challenges in terms of time and resources. SME foundries have no separate budget for employee development activities [4].Unit level efforts have hardly been publicized for the knowledge of the researchers.

There is a growing emphasis to exploit the potential of SMEs looking at their importance, as recognized by Government of India since 2006. MSMD Act 2006 was enacted to support MSME sector to enable them to upgrade their technology and fulfill their training needs. Apart from the external support, internal environment of the SMEs needs to be focused to dedicate their resources to develop their employee skills. The qualitative study by Agarwal and Jha (2015) [5] indicate that SMEs have mostly unstructured and informal process for training that depend on the owners' or managers' priority list.

Presently many foundries are facing talent crunch, due to the demand for skilled manpower from other sectors. Work environment in foundries is very challenging and new generation of workers are reluctant to stay long in such environment. The challenge is also to upgrade foundries to become green foundries. This change requires skilled workforce to operate in automated environment.

Literature suggest that it is important to understand the factors that drive employee development in SMEs in their specific context. [6]

\section{RESEARCH METHODOLOGY}

Considering the gap reflected through literature survey, the study was designed to explore the skill development practices in foundry units. Survey method was used to collect the information required. Survey was conducted in 100 units and 800 responses were collected.

Research instrument in the form of structured questionnaire was prepared to collect the data. Seven statements related to skill development practices, were included in the questionnaire. The respondents were ask to rate their agreement with the statement on the 5 point Likert Scale, from "Strongly Agree", Agree, Neutral, Disagree, and Strongly Disagree"

\section{FINDINGS AND ANALYSIS}

$97 \%$ of the foundries in the study belong to small and 3\% belong to medium scale category. Profile of the respondents include $5 \%$ owners, $21 \%$ managers, $18 \%$ administrative and $30 \%$ technical staff, and $25 \%$ shop floor workers. Findings below show the opinion of the employees about the skill development practices in their units. All foundry units have quality certification and majority of them are operating since 10 to 15 years.

\section{Table 1: Finding 1}

\begin{tabular}{|c|c|c|}
\hline $\begin{array}{c}\text { Organization regularly offers } \\
\text { training and development } \\
\text { programmes for employees' skill } \\
\text { development }\end{array}$ & Frequency & Percent \\
\hline Neutral & 43 & 5.4 \\
\hline Agree & 722 & 90.3 \\
\hline Strongly Agree & 35 & 4.4 \\
\hline Total & 800 & 100.0 \\
\hline
\end{tabular}

Table 1 indicate that over $90 \%$ of the respondents agree that their organizations provide training regularly. 


\section{Table 2: Finding 2}

\begin{tabular}{|c|c|c|c|}
\hline \multicolumn{2}{|c|}{$\begin{array}{c}\text { Employees are } \\
\text { rewarded/recognized for } \\
\text { upgrading their skills }\end{array}$} & Frequency & Percent \\
\hline \multirow{4}{*}{ Valid } & Neutral & 47 & 5.9 \\
\cline { 2 - 4 } & Agree & 707 & 88.4 \\
\cline { 2 - 4 } & Strongly Agree & 46 & 5.8 \\
\cline { 2 - 4 } & Total & 800 & 100.0 \\
\hline
\end{tabular}

Table 2 indicate that over $88.4 \%$ of the respondents agree that their skills are rewarded/recognized in their organization.

\section{Table 3: Finding 3}

\begin{tabular}{|c|c|c|c|}
\hline $\begin{array}{c}\text { Employees are encouraged to apply their } \\
\text { new knowledge and skills in their work }\end{array}$ & $\begin{array}{c}\text { Freque } \\
\text { ncy }\end{array}$ & Percent \\
\hline \multirow{4}{*}{ Valid } & Neutral & 16 & 20 \\
\cline { 2 - 4 } & Agree & 769 & 96.1 \\
\cline { 2 - 4 } & Strongly Agree & 15 & 1.9 \\
\cline { 2 - 4 } & Total & 800 & 100.0 \\
\hline
\end{tabular}

Table 3 indicate that majority of the respondents are encouraged to apply their new knowledge at work.

\section{Table 4: Finding 4}

\begin{tabular}{|c|c|c|c|}
\hline \multicolumn{2}{|c|}{$\begin{array}{c}\text { Employees are provided with } \\
\text { feedback on their work to know } \\
\text { their area of improvement }\end{array}$} & Frequency & Percent \\
\hline \multirow{4}{*}{ Valid } & Neutral & 51 & 6.4 \\
\cline { 2 - 4 } & Agree & 711 & 88.9 \\
\cline { 2 - 4 } & Strongly Agree & 38 & 4.8 \\
\cline { 2 - 4 } & Total & 800 & 100.0 \\
\hline
\end{tabular}

Table 4 indicate that the foundries practice feedback system to make their employees, know their improvement area.

\section{Table 5: Finding 5}

\begin{tabular}{|c|c|c|c|}
\hline $\begin{array}{c}\text { Employees learn by sharing their } \\
\text { knowledge and expertise with } \\
\text { each other }\end{array}$ & Frequency & Percent \\
\hline \multirow{4}{*}{ Valid } & Neutral & 48 & 6 \\
\cline { 2 - 4 } & Agree & 708 & 88.5 \\
\cline { 2 - 4 } & Strongly Agree & 44 & 5.5 \\
\cline { 2 - 4 } & Total & 800 & 100.0 \\
\hline
\end{tabular}

Table 5 show that most of the employees learn by sharing their expertise. It was observed that the supervisors were the primary source of knowledge.

\section{Table 6: Finding 6}

\begin{tabular}{|c|c|c|c|}
\hline \multicolumn{2}{|c|}{$\begin{array}{c}\text { Employee feedback is taken after } \\
\text { every training programme }\end{array}$} & Frequency & Percent \\
\hline \multirow{4}{*}{ Valid } & Neutral & 13 & 1.6 \\
\cline { 2 - 4 } & Agree & 777 & 97.1 \\
\cline { 2 - 4 } & Strongly Agree & 10 & 1.3 \\
\cline { 2 - 4 } & Total & 800 & 100.0 \\
\hline
\end{tabular}

The finding reveals that feedback is taken after every training programme, as per Table 6. This was found to be the good practice that generally practiced in large organizations.

\section{Table 7: Finding 7}

\begin{tabular}{|c|c|c|c|}
\hline $\begin{array}{c}\text { Employee Skill Mapping is done } \\
\text { regularly }\end{array}$ & Frequency & Percent \\
\hline \multirow{4}{*}{ Valid } & Neutral & 10 & 1.3 \\
\cline { 2 - 4 } & Agree & 785 & 98.1 \\
\cline { 2 - 4 } & Strongly Agree & 5 & 0.6 \\
\cline { 2 - 4 } & Total & 800 & 100.0 \\
\hline
\end{tabular}

As per Table 7, majority of the foundries have skill mapping in place. This helps foundries to identify skills, profile skills of employees and find gaps to plan skill development activities.

\section{CONCLUSIONS}

Though the scenario for skill development in SMEs is not so |www.worldwidejournals.com encouraging as per literature on SMEs, the foundries in the study area were found to be having conducive environment for skill development. There is a scope for future research to study, whether all employees equally get an opportunity for undergoing training programme. It will be also interesting to note that majority of the respondents, belonged to technical and managerial work, who usually receive formal training related to their work. But, skill development is equally important for non-technical staff. The study limits generalization of finding that all SME foundries have favorable environment for skill development. The study needs to be repeated in other foundry cluster to understand the similarity to the findings of the present study. The skill development can be studied considering different skills like managerial skills, technical skill and people skills. Skill mapping process in foundries can also be an value added research in future, to compliment the efforts of National Skill Development Council (NSDC) in India.

\section{REFERENCES:}

[1] Singh, B. J., \& Khanduja, D. (2012). Scope of Six Sigma in Indian foundry operations: a case study. International Journal of Services and Operations Management, 13(1),65-97.

[2] ttps://www.researchandmarkets.com/research/s5r739/the_foundry?w $=4$

[3] Cecilia Wong, J. Neill Marshall, Neil Alderman \& Alfred Thwaites (1997) Management training in small and medium-sized enterprises: methodological and conceptual issues, The International Journal of Human Resource Management, 8: 1,44-65

[4] Singh, B. J., \& Khanduja, D. (2012). Scope of Six Sigma in Indian foundry operations: a case study. International Journal of Services and Operations Management, 13(1),65-97.

[5] Agarwal, U. A., \& Jha, S. (2015). Human Resource Practices in Indian SMEs - An Exploratory Study. Indian Journal of Industrial Relations, 50(4), 680-695.

[6] Nolan, C.T., \& Garavan, T.N. (2016). Human Resource Development in SMEs: A Systematic Review of the Literature: Human Resource Development in SMEs. International Journal of Management Reviews, 18(1), 85-107. 